\title{
Private funding and management for public interchanges in Madrid
}

\author{
María Eugenia Lopez-Lambas , Andres Monzon \\ TRANSyT (Transport Research Centre), Universidad Palitecuica de Madrid, Spain
}

Keywords:

Interchanges

Public-private partnership

PT stakeholders participation

\begin{abstract}
A B S T R A C T
Interchanges are key elements for improving seamless mobility in metropolitan areas where multistages trips are increasing. Interchange facilities make transfers short, easy and comfortable, and therefore Public Transport (PT) trips became more attractive and competitive. However. good quality interchanges are rather expensive, especially with regard to construction and operation. The solution launched in Madrid was a public-private scheme where all stakeholders involved play a key role. The first experience was Avenida America Interchange in the border of Madrid CBD, which opened in 2000. The construction was carried out through a Build and Operate and Transfer (BOT) tender. Three public bodies were involved: Municipality, Regional Government and Public Transport Authority. The concessionaire was a company constituted by a transport operator, several construction companies and a national bank. The revenues came from a fee which pays every bus using the facility, some shops, two parking lots, and other business. This positive experience has been extended to the construction of four new interchanges that were inaugurated in the years 2007 and 2008.
\end{abstract}

\section{Development of a network of interchanges}

The process of urban sprawl in most cities leads to situations in which public transport loses competitiveness. Trip patterns in metropolitan areas are increasingly complex, it is very difficult to provide door-to-door public transport services, and public transport (PT) trips are becoming longer and multi-modal. To compete with the car as the main mode of transportation, a key factor is to provide seamless PT mobility. This calls for integration in two different aspects of PT: plyysical integration of the tijp chain and payment systems.

But physical integration requires interchange facilities to make transfers short, easy and comfortable (Hoogendoorn-Lanser, Van Nes, \& Hoogendoorn, 2006). As Hine and Scott wrote (2000), "Emphasis on the need to reduce deterrence effects and cost associated with interchange, so that increasingly seamless public transport journeys can be provided is now a key policy goal."

The basis for this statement is that passengers show a very negative perception of waiting and transfer times at PT stops, providing a subjective value 1.5-2 times higher than the actual time. Therefore, it becomes necessary to minimise "not-on-board time" and to reduce the associated negative perception, which could partially be solved by using technology and telematics solutions designed to create as seamless a journey as possible from the point of view of the transport system user (Blythe, Rackliff, Holland, \& Mageean, 2000).

\subsection{The problem of financing}

But the construction of a transport interchange station in a consolidated urban zone within a metropolitan environment implies a large investment that, upon being directly assumed by the Administration, requires the dedication of limited resources that are often not considered as a part of the budget.

Transport interchanges are one of the key elements that transport authorities need to foster the use of public transport and improve seamless mobility. Unfortunately, as stated above, this kind of infrastructure is very expensive to build and maintain. This fact makes indispensable the organisation of new funding schemes that, without relinquishing public ownership, allow the entrance and participation of private entities. A quick overview of the PT interchanges existing in European cities shows that their funding is based on the public initiative. Certainly there are agreements between different bodies, but all of them are from the public sector.

So we must face another critical question: who should pay? Operators have an unquestionable interest in improving the performance of the services they provide, but they lack money for investments. On the other hand, public bodies have many other priorities such as hospitals, schools, traffic control, etc. Last but not least, the users are not willing - or able - to pay higher fees for using better PT facilities. It is true that the need for public funding should be clearly recognised in order to allow PT to fulfil its potential (UITP, 2003); but that said, why not use the public-private partnerships scheme to support the construction - not 
only the operation - of public transport infrastructure? This has been the wager of the Madrid Regional Transport Authority.

\subsection{The development of a network of interchanges for public transport modes in Madrid}

The bid for PT in Madrid faced a serious problem when the city started to suffer a suburbanisation process that lead to a higher competitiveness of cars against PT that, in turn, initiated the decline of PT in the suburbs: unimodal PT trips become multi-modal. In fact, PT is potentially less competitive because of the increasing number of journeys with two or more stages. Though it is clear that another possibility is to implement disincentives for automobile trips, this is out of the political agenda of Madrid. To keep PT attractive, the only solution seems to be to improve the system performance (Cassello, 2007).

The Madrid Public Transport Authority was aware of the need to integrate different PT services: urban buses, metro, commuter rail, metropolitan buses and trams (Aldecoa, 2002). Apart from providing an integrated travelcard for all PT, the need for constructing interchanges in a number of key transfer points within the boundaries of the City of Madrid was envisioned.

The first project started in 1986, with the Aluche Interchange (South), and finished with the interchange in Plaza de Castilla (North), inaugurated in 1993. Both were designed and built with low construction and maintenance costs. However, both are outdoors with a low level of comfort and lack waiting areas, shops, etc. (Fig. 1)

\section{Promoting new interchanges without public funding}

The rapid sprawl experienced by the Madrid Metropolitan Area has increased the need for more and larger interchanges; but to assure seamless mobility today, it is necessary to provide more than the usual transfer facilities. Travellers demand comfort, information, safe waiting spaces protected from bad weather, and other facilities (shops, bars, etc.).
At the same time, transport operators demand space for better bus operation and rail services. They require space for vehicles and for stopping and taking on passengers, parking for buses, ticket offices, information offices, etc.

This means that interchanges must be more than just a place to wait on the street: they require buildings that are specially designed to this end and that join services for operators, public transport authorities and users. All of these things foster better integration of services, but require great monetary investments. Therefore, the question is how to improve interchanges without increasing both the burden for the public budget and the cost of transport services.

The solution comes hand-in-hand with an integrated vision of the new interchanges, where all stakeholders participate, each of them supporting the project according to their expected profits. This calls for a change in the traditional separation of and roles played by private and public entities in these matters; in other words, it requires the application of the Public-Private Partnership (PPP) model to urban transport interchanges (Cristóbal, Rodríguez, \& Aldecoa, 2000).

\section{The first privately funded project: the Avenida America Interchange}

\subsection{The players, the circumstances}

In 1997, an interurban bus transport operator - Continental Coaches, Ltd. - was looking for a new location for its old bus terminal in Madrid which was experiencing serious capacity problems at the time.

Meanwhile, the Madrid Public Transport Authority was looking for a creative financing formula with which to build a new interchange on the eastern border of the City of Madrid. New developments in the region and a connection with the enlarged Madrid Airport made finding a solution for building an interchange in the area a major priority. However, the problem of funding such a large investment remained an obstacle.

Perhaps both problems could be solved by looking for a joint solution.
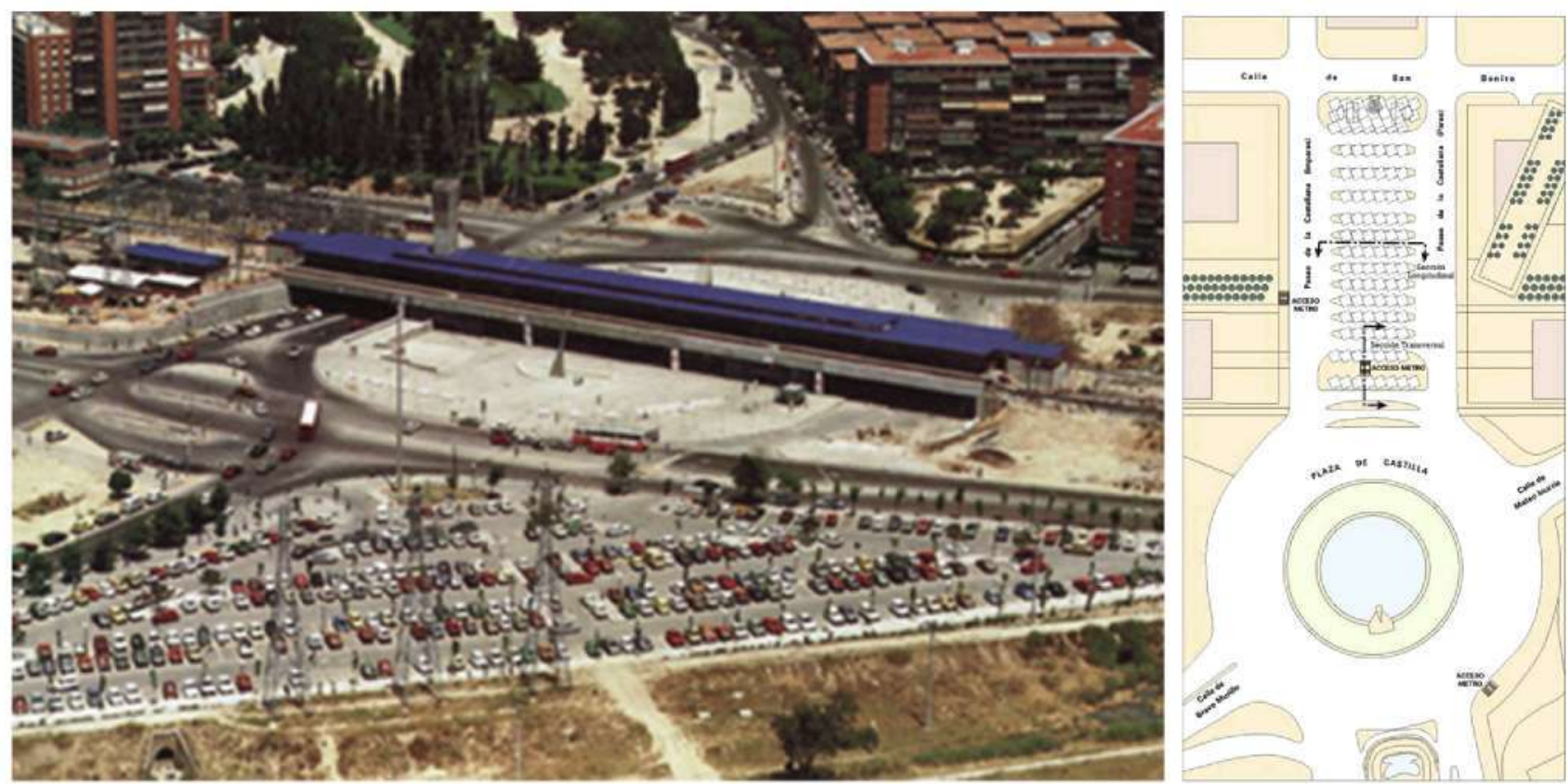

Fig. 1. Old interchanges in Madrid: Aluche and Plaza Castilla. 


\subsection{The concessionary design}

Once the situation was analysed according to the Spanish regulatory system, it became clear that the only possible way to make the new interchange a reality was to launch a concessionary tender on a Build and Operate and Transfer (BOT) basis. The most convenient location was chosen: Avenida America, an urban space near the intersection of the A-2 motorway (east) and the M-30 ring road.

The Madrid Regional Government took the leadership role in promoting the Avenida America Interchange and the process was started, beginning by identifying all possible interested parties from the public side:

1. The Municipality of Madrid (owner of the land) was interested in the project, as it is responsible for running the urban buses of Madrid, with several lines and stops to be affected by the new infrastructure. But the Municipality expected many complaints from the neighbours who would lose a precious parking area. In the end, it released the land on the unavoidable condition that new parking for area residents be provided.

2. The Madrid Public Transport Authority was interested in connecting long-distance, metropolitan and urban bus services with each other and with the metro network.

3. The Madrid Regional Government - Transport Infrastructures Department - the third major player, was the body in charge of building new public facilities for transport in the region.

The three parties signed an agreement assigning roles and responsibilities with regard to the project. Finally, in December, 1997, they launched an open tender for the BOT of the Avenida America Interchange. The preliminary budget was some $€ 25$ million, and the bidder would be required to offer a plan for the construction of a building that would include the following:

- Floor for interurban bus services

- Floor for metropolitan bus services

- Parking lot for residents in the area

- Public parking facility

- Direct connection for buses via tunnel with the A-2 motorway

- Good connection with metro and urban bus services

- Space for shops and transport services

There was another condition: the operation had to start in a maximum of two years time. The concessionary period was set for a maximum of 25 years.

In exchange, the three public entities offered the concessionaire:

- Use of the interchange, which would provide access to users from the 18.8 million passengers currently using Madrid metropolitan bus services, though the concessionaire would be required to pay $€ 0.06$ per passenger using the metropolitan lines at the interchange

Table 1

Winning consortium of Avenida America tender.

\begin{tabular}{lll}
\hline Sector & Name & $\begin{array}{l}\text { \% Share in } \\
\text { consortium }\end{array}$ \\
\hline Interurban transport operators & Continental auto & $25 \%$ \\
& TRAPSA & $25 \%$ \\
Construction companies & ACS & $20.5 \%$ \\
& Ferrovial & $20.5 \%$ \\
Bank & Argentaria & $5 \%$ \\
Installations company & Cobra & $3 \%$ \\
Consultant company & PROINTEC & $1 \%$ \\
\hline
\end{tabular}

- Possible users from the 89 million passengers from four metro lines that stop in Avenida America

- Possible users from the 3.6 million passengers of the urban bus lines in the area

- Opportunity to lease parking lots for area residents from the Municipality by making an advance payment for its use for 50 years

\subsection{The bidding, construction and operational phases}

Several consortia prepared a bid for the Avenida America Interchange. The ideal consortium would be one that contained the following types of companies: interurban bus operators, builders, lenders and other possible service providers. Each would receive profits for their own business.

After four months of consideration, the selected winner was a consortium formed as follows: (Table 1)

The consortium had all the key players: transport operators, construction companies, financial partners, and consultants. The operators were interested in providing a place from which to operate in a central location in Madrid. The construction and consultant companies would be engaged in building the interchange and Argentaria would profit from providing the financial resources.

The construction started in June 1999, and finished in January $2000-$ a record construction time of only one and a half years. One of the reasons for this rapid progress is that the concessionaires would begin to earn money only when the interchange was in operation. In other words, they needed to reduce the construction period as much as possible to begin to profit from the investment. (Fig. 2)

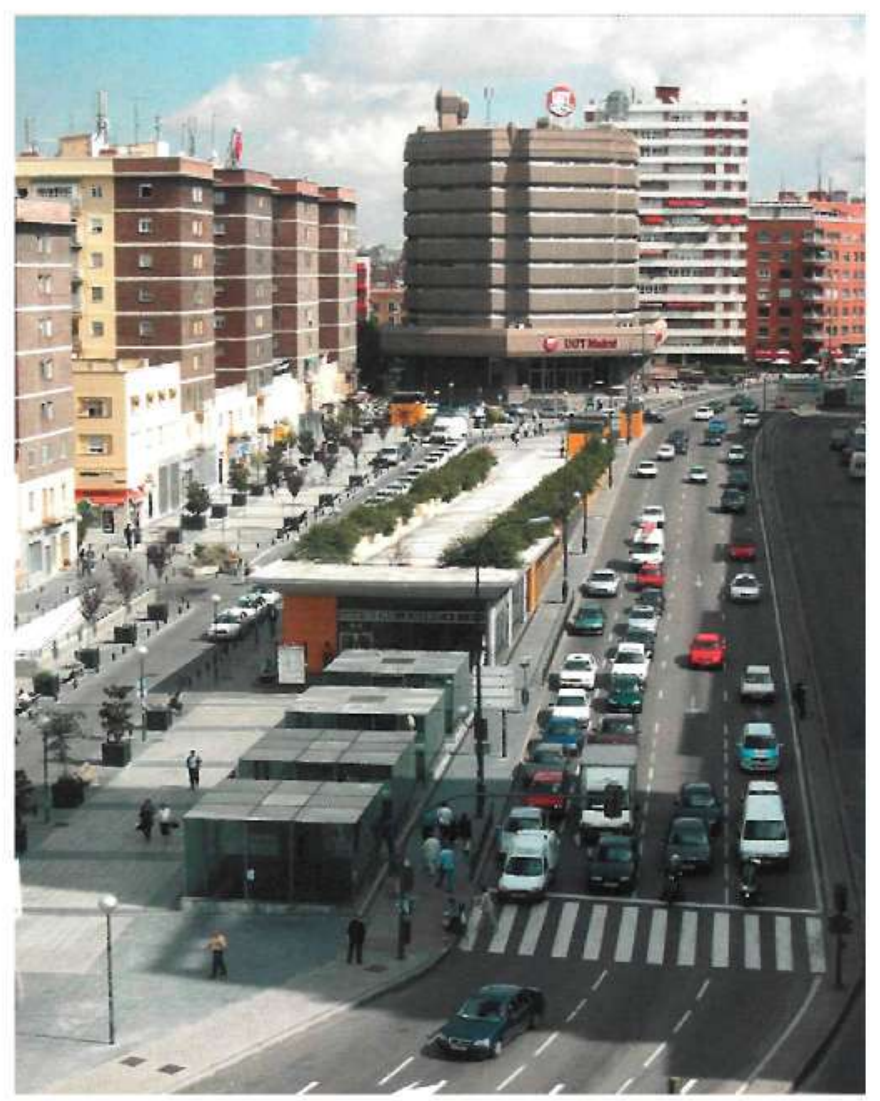

Fig. 2. Inauguration (7.1. 2000) and external layout of Avenida America Interchange. 
Table 2

Financing scheme for construction of the Avenida America Interchange.

\begin{tabular}{lll}
\hline & $€($ millions $)$ & $\%$ \\
\hline Total investment & 25.62 & \\
Equity capital & 4.5 & 18 \\
Revenues from 396 parking places & 3.16 & 12 \\
$\quad$ for area residents (1251€ each) & & 70 \\
Algentaria loan (5.5\% interest rate) & 17.96 & \\
\hline
\end{tabular}

The project, which required the construction of four underground levels, included the following:

- 37 platforms for buses on two levels: interurban and metropolitan

- $1342 \mathrm{~m}^{2}$ for commercial activities

- $523 \mathrm{~m}^{2}$ for offices

- parking floors: public and residential

- Information office, baggage lockers and other services for travellers

The Avenida America Interchange also has the following characteristics for providing better accessibility:

- $480 \mathrm{~m}$ two-way bus tunnel connecting the interchange to the A-2 motorway

- Direct connection to four metro lines

- Taxi stop at street level

- Bus stops for urban buses at street level corresponding to 11 lines

- Platforms for 14 lines of metropolitan bus services

- Platforms for all Madrid services for interurban bus operators Continental and TRAPSA

Being a concession project, the financing of the Avenida America Interchange was entirely private. The distribution of the costs among the financial stakeholders is shown in Table 2 .

It is worth mentioning that one of the key elements in acquiring the necessary funds was the building of parking lots for area residents, as this provided $12 \%$ of the initial resources, reducing the need for loans to complete the project.

\subsection{Results: the expected and the unexpected}

The Avenida America consortium was concerned with the risk of basing the financing of their investment on travellers using the facility on a voluntary basis. However, the revenues were higher than planned, though different from what was expected.

The following table shows the financial short- and mediumterm results: (Table 3)

The results show that the majority of the income - more than $55 \%$ - is generated by the collection of fees from transport operators who attract more passengers due to better accessibility and good transfer facilities for metro and urban buses. It is relevant to mention that the operators pay a fee of $€ 0.06$ per passenger, which results in an increase in their costs. However, they compensate for this additional cost by attracting more passengers and by taking advantage of the lower operating costs, as they do not pay for their own bus terminals. It is also significant that almost half of the revenue comes from secondary businesses: parking, renting space for shops and other businesses (publicity, vending machines, mobile telephones, etc). All the revenue is much higher than planned and has continued to increase over the years.

As for the cost, there are also significant differences between the actual and the planned expenditure. It is clear that the concession was beneficial from the beginning, as a significant amount of money was dedicated to an early pay-back of the loan, reducing interest and taxes immediately. However, the increased number of users led to greater operating costs. In addition, the Transport Authority has demanded that services be of higher and higherquality, and therefore operational costs have increased in greater proportion than the number of users.

Certainly, the change in the distribution of incomes and expenditures is notable, since it was planned that the ratio between transport fees and operation costs be 1.6 , but in 2007 it was only 1.1 On the other hand, this means that the transport business hardly covered its direct costs, and the fact is that there are much higher revenues from other sources that make the concession a good business.

The Avenida America Interchange accomplished what the Madrid Regional Government wanted: to find a Public-Private Partnership formula to continue building new interchanges - and renovating old ones - without being a burden for the Regional Budget.

\section{Extension of the experience: a new era of interchanges in Madrid}

The construction of the Avenida America project enabled the administration to acquire the know-how to properly guide a complicated project such as this. It also allowed the construction

Table 3

Evolution of revenues and costs in the Avenida America lnterchange.

\begin{tabular}{|c|c|c|c|c|c|c|c|c|c|c|}
\hline \multirow[t]{2}{*}{ Financial Year } & \multicolumn{2}{|c|}{ Planning years } & \multicolumn{2}{|l|}{2000} & \multicolumn{2}{|l|}{2001} & \multicolumn{2}{|l|}{2007} & \multicolumn{2}{|c|}{ Evolution } \\
\hline & Planned & $\%$ & Real & $\%$ & Real & $\%$ & Real & $\%$ & $07 / 01$ & 07/planned \\
\hline \multicolumn{11}{|l|}{ incone statement: } \\
\hline Transport operators & $1,474,138$ & 54 & $2,400,324$ & 62 & $2,244,342$ & 57 & $2,727,596$ & 55 & 22 & 85 \\
\hline Shops & 594,828 & 22 & 631,008 & 16 & 786,720 & 20 & $1,134,017$ & 23 & 44 & 91 \\
\hline Public parking & 310,345 & 11 & 124,842 & 3 & 295,950 & 7 & 579,356 & 12 & 96 & 87 \\
\hline Other's & 367,241 & 13 & 691.578 & 18 & 640.944 & 16 & 503.460 & 10 & -21 & 37 \\
\hline Total income & $2,746,552$ & 100 & $3,847,752$ & 100 & $3,967,956$ & 100 & $4,944,429$ & 100 & 25 & 80 \\
\hline \multicolumn{11}{|l|}{ Expenditures: } \\
\hline Operation costs & 905.172 & 32 & $1,263.582$ & 38 & 1.446 .504 & 37 & $2,411.751$ & 53 & 67 & 166 \\
\hline Taxes & 92,880 & 3 & 62.928 & 2 & 107.232 & 3 & 15.721 & 0 & -85 & -83 \\
\hline Loan interest & 980,100 & 34 & 896,682 & 27 & 852,492 & 22 & 547,010 & 12 & -36 & -44 \\
\hline Loan amortisation & 878,160 & 31 & $1,121,196$ & 34 & $1,556,478$ & 39 & $1,578,821$ & 35 & 1 & 80 \\
\hline Tatal expenditures & $2,856,312$ & 100 & $3,344,388$ & 100 & $3,962,706$ & 100 & $4,553,303$ & 100 & 15 & 59 \\
\hline Profits & $-\log _{, 761}$ & & 503,364 & & 5250 & & 391,126 & & & \\
\hline
\end{tabular}


Table 4

New generation of interchanges in Madrid, Spain.

\begin{tabular}{lrrrrrr}
\hline & $\begin{array}{l}\text { Avenida } \\
\text { America }\end{array}$ & $\begin{array}{l}\text { Plaza } \\
\text { Castilla }\end{array}$ & $\begin{array}{l}\text { Plaza } \\
\text { Eliptica }\end{array}$ & $\begin{array}{l}\text { Principe } \\
\text { Pí }\end{array}$ & Moncloa \\
\hline Start operation year & 2000 & 2007 & 2007 & 2007 & 2008 \\
Investment (millions $\epsilon$ ) & 24 & 102 & 36 & 50 & 97.2 \\
Concession period (years) & 25 & 35 & 35 & 35 & 35 \\
Area built $\left(\mathrm{m}^{2}\right.$ ) & 41,500 & 74,350 & 29,700 & 28,300 & 46,000 \\
Length of tunnels (m) & 480 & 1,250 & 600 & 400 & 1,000 \\
Car parking spaces offered & 665 & 400 & - & - & - & 36 \\
Platforms (number) & 36 & 45 & 20 & 32 & 36 \\
Demand (passengers/day) & 445,400 & 269,300 & 126,300 & 299,200 & 360,000 \\
Metropolitan bus lines & 14 & 37 & 14 & 13 & 35 \\
Urban bus lines & 11 & 16 & 10 & 8 & 14 \\
Metro lines & 4 & 3 & 2 & 3 & 2 \\
Suburban railway lines & - & - & - & & 2 & - \\
Long distance bus & 2 & 0 & 1 & 1 & 0 \\
$\quad$ operators & & & & & \\
\hline
\end{tabular}

Source: Pedro Saldaña (2008).

companies to discover a new business sector, where they can develop profitable projects that combine construction benefits in the short run with operational benefits in the long run.

In the case that we show here, the infrastructure does not generate any debt for the Public Administration; rather than this, within this scheme the Madrid Regional Government, the Madrid City Council and the Madrid Transport Authority have built up, in the last years, by the Contract for Public Work Concession, five transport interchange stations, whose investment and operation were privately financed throughout the concession period; the first of all, this from Avenida America (CRTM, 2009).

\subsection{New generation of interchanges in Madrid}

Using the same framework, the Madrid Public Transport Authority launched another set of concessions to build new and better interchanges. There are four interchanges located on the border of the centre of Madrid: Plaza Eliptica, Príncipe Pío, Plaza Castilla and Moncloa. The first two had been constructed only recently. The latter two were existing interchanges with capacity problems due to increased demand; they posed a problem because, as they are directly operated by the Public Transport Authority, their costs are charged to the Regional Budget.

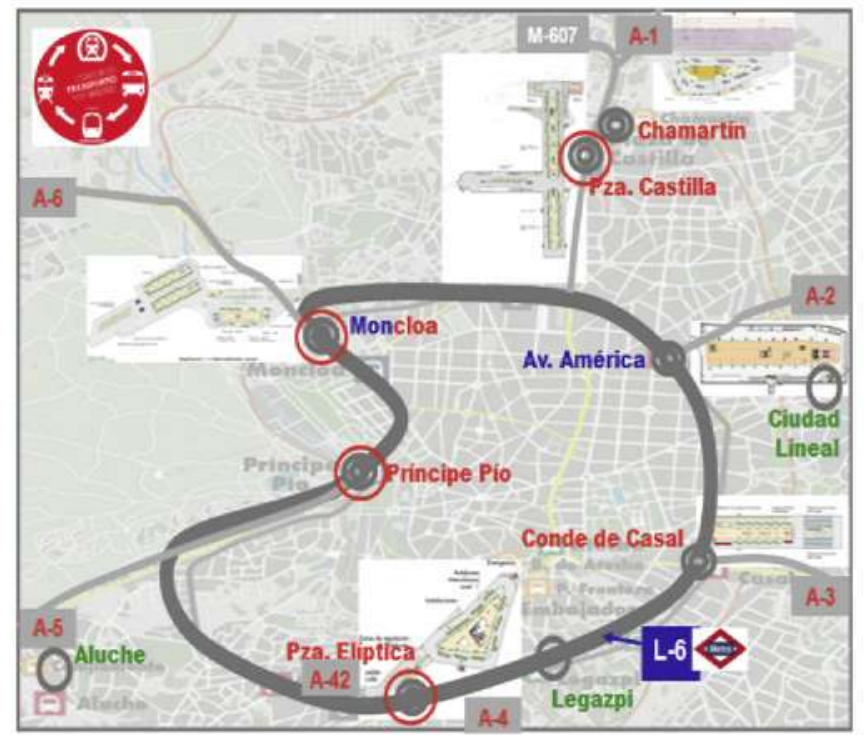

Fig. 3. Madrid Interchange Network.
These new projects were designed with the following general characteristics in mind:

- Maintain the underground terminal concept, but with even greater size and capacity and with bus access tunnels needed to obtain important time savings

- Finance privately as a public concession

- Improve conditions for passengers: air conditioning, waiting areas without smoking

- Renovate the urban design at street level to improve local integration and give priority to pedestrians

Table 4 shows the main figures which indicate the value added by the new generation of interchanges.

This new generation of interchanges was finished in 2008 and, as was foreseen, greatly improved the transfer conditions of multimodal trips in the Region of Madrid. Each of these interchanges offers high quality services, both for operators and citizens. Their daily demand is some 1.5 million transfer passengers.

The location of the five new generation interchanges is shown in Fig. 3, marked by red circles. Litman (2009) proposes better coordination of transport services as a crucial way to avoid automobile dependency. The goal should be to address the lack of service integration among various transport operators, which is the most important deterrent effect reported by Wardman and Hine (2000). The network of interchanges shown in Fig. 3 addresses these issues, makes PT more attractive and offers PT journeys that are highly competitive with car trips in the Madrid area.

\section{Conclusion: a win-win situation}

There is a general consensus on interchanges as one of the main tools to enable modal redistribution and to enhance the public transport use. In fact, there is no doubt that they constitute a decisive factor in people's transport-related choices. Interchange points represent an opportunity to change the erosion of public transport image and, hence, to improve its use in terms of an increasing number of people (CRTM, 2009). But the financing of the public transport infrastructures makes necessary to create the conditions necessary for a public-private sector partnership investment in multi-modal schemes with flexible profit sharing arrangements that contribute to reduce risks to all parties and enable speedier progress the project implementation (LINK, 2010).

The building of new interchanges using a PPP system is a winwin situation where maximum value for money is obtained. The Madrid Public Transport Authority is a winner because it has been able to build five new interchanges of exceptional quality in a very short period of time, at no cost to the public budgetary resources. The operators win because they attract more passengers and are able to offer higher-quality services. The passengers are also winners because their intermodal trips now have seamless transfers, better information, waiting areas and other valuable services. Society in general benefits as public transport services attract more trips, becoming more competitive against cars than ever.

However, the experience from Avenida America seems to confirm that the success of an interchange depends not only on the quality of the transport services, but also on a number of factors associated to the perceived quality of the interchange (Hine \& Scott, 2000). In our case study these factors were: quality of waiting environment, information desk, personal security, timetable and other trip information services, etc; but, since all these services cost money, they should be considered in the budget of the interchange.

Finally, the 2007 EC Green Paper stated that "citizens expect collective transport to meet their needs for basic mobility and to satisfy their needs for accessibility" (European Commission, 2007). 
In this sense, the experience of a new partnership to improve the attractiveness of public transport trips in metropolitan areas is a step in the right direction.

\section{References}

Aldecoa, J 11-13 June 2002. Grandes intercambiadores metropolitanos: Los casos de Madrid. V Congreso de Ingeniería del Transporte (pp. 2239-2346). Santander.

Aldecoa. J., Garcia, C., Ruiz. A., Lopez, 5., Rodriguez. J., Criado, C., et al. (2009). Plan de intercambiadores de Madid. Madrid: Consorcio Regional De Transportes De Madrid (CRTM)

Blythe, P., Rackliff, T., Holland, R., \& Mageean, J. (4-6 April 2000). The potential for ITS in improving and integrating services at uban transport interchanges for public transport. 10th international conference on road transport information and control, 2000, Vol. 472 (pp. 192-199). London.

Cassello. J. M. (2007). Transit competitiveness in polycentric metropolitan regions. Transportation Research Part A-Policy and Practice, 41(1), 19-40.

Cristóbal, C., Rodríguez, ], \& Aldecoa, J., (23 November 2000). Contracts for financing transport infrastructure: case of the Avenida America interchange in Madrid.
E.M.T.A. Workshop "Contracts: $A$ tool for public transport autharities" (pp. 44-53) Rome.

European Commission. (2007). Green paper towards a new cuiture for urban mobility. Brussels: European Commission CoM/2007/551.

Hine, J. \& Scott, J. (2000). Seamless, accessible travel: users' views of the public transport joumey and interchange. Transport Policy, 7, 217-226.

Hoogendoorn-lanser, 5., Van Nes, R., \& Hoogendoorn, 5. P., (2006). Modeling transfers in multi-modal trips - Explaining correlations. 85th Anmal meeting of the transportation-research-board. Traveler Behavior and Values 2006 (pp. 180-187). 1985.

Litman, T. (2009). Introduction to multi-modal transportation planning. Principles and Practices, Victoria Transport Policy Institute. www.vtpi.org.

Saldaña, P. 2008. Master Thesis on financing PT infrastructures in Madrid. UPM

The European Forum on Intermodal Passenger Travel (LINK), 2010. Final Repart: Recommendations and Strategies for passenger intermodality in Europe. European Commission 6th Framkework Programme 2002-2008 (www. linkforum.eu).

UITP. (2003). The financing of public transport operations. http://www.uitp.org/ advocacy/positions.cfm UITP position paper, April 2003.

Wardman, M. \& Hine, J. P. (2000). Costs of interchange: A review of the literature. Working Paper 546. Institute for Transport Studies, University of Leeds. 